\title{
SHIFTING INTERPRETATION OF JOHN KERRY'S SPEECH ABOUT SYRIA CONFLICT REPORTED BY KOMPAS TV
}

\author{
Sheellviana Dewi, Dian Rivia Himmawati \\ Universitas Negeri Surabaya, sheellvianadewi@mhs.unesa.ac.id \\ Universitas Negeri Surabaya dianrivia@unesa.ac.id
}

\begin{abstract}
The issue of John Kerry's speech about Syria conflict reported by Kompas TV takes interpretation process. Interpretation used in transforming source language (John Kerry/English) to target language (Kompas TV/Indonesian). The aim of this study is revealing shifting interpretation inserted by Kompas TV while reporting John Kerry's speech about Syria conflict. Documentary video from Kompas TV and the United States official channel on YouTube is the data which consist of three videos. Qualitative data approach is applied to this study because the analysis gives explanation to strength the findings. The result of the analysis shows that Kompas TV used complex syntax, making long passage into a sentence, deverbalization, and compression to get John Kerry's idea. All of John Kerry's utterances are simplified into the simple one. Hence, Kompas TV shifts the interpretation through complex syntax process which is inserted in semantic macrostructures, syntactic of subject position, self-define of terrorist, and disclaimer to reject racism.
\end{abstract}

Keywords: interpretation, cognitive context, shifting, Syria.

\section{INTRODUCTION}

Interpretation is a bridge for two languages; source language and target language. In the international news, interpretation is needed for reporting event in the other places with different language. As in Kompas TV news report which has John Kerry as a source language. Kompas TV, one of television programs in Indonesia, delivers the news in Indonesian, and John Kerry, who was American Ministry of Foreign Affairs in 2016, speaks in English. In his speech, John Kerry 
mentioned three steps for negotiating peace in Syria, and all of them indicate shifting interpretation by Kompas TV.

Interpretation has strategies to overcome the speaker's complexity and fast speed (Nolan, 2005). The organization of meaning can be shifted in the context. Besides, cognitive context models theory is elaborated to reveal shifting meaning by relating the context models and discourse structures. The analysis of Kompas TV interpretation for John Kerry's speech is exciting. It has not been done by the previous studies which discuss about shift translation in the novel (Putra, 2015) and cognitive used in the parliament for recognizing the participant' idea by Alicja (Okoniewska, 2016).

This study purposes to analyze the strategies used by Kompas TV narrator to interpret John Kerry's idea. Additionally, exposing shifting interpretation which might be given by the narrator is also emphasized in this research. It is important to criticize the content of interpreted media, which consists of meaning biased about the event. The result can be used for showing that interpretation can be manipulated by shifting the meaning controlled by the context.

\section{Context Models and Discourse Structures}

Cognitive as linguistics device discovers people's way of thinking or processing information. It starts with event models and interpreted by mental models. For instance, people's opinion of accident (event) is various, such as: something causing traffic jam, or something causing people injured. It is mental models that process the information based on personal knowledge and social group beliefs (Dijk, 1997). Next, the information in the mental models is built by the concept of context models, for example the speakers always have intention of their speech. It takes control the audience perception while processing the information (event).

224 | http://journal.unesa.ac.id/index.php/paramasastra 
In context models, meaning structures is the main function, such as using local coherence. Contextual determines that discourse structures affect the organization of meaning. Relating context models and discourse structures divided into seven parts below.

\section{Surface Structures of Semantic Structures}

The expression of the content is called as surface structure. It managed by semantics for the event models, both are controlled by context models. For example, addressing people by using pronounce such as Mr. Steve or Professor Steve. It affected by the social relation between speech participants, which is represented in context models then. In discourse, defining the topic to express event model requires macrostructures for it states all into one. To support the topic, microstructures work in giving the detail information. Semantic macrostructures provide the coherence to construct the topic in a discourse. It is usually showed by the headlines of the news. The expression manages semantic information by micro-level related to overall meaning.

\section{Schematic Structure in Event Models}

Schematic structures or superstructures are involved in conveying overall meaning (topic) of the discourse. It appears in types such as narrative, argumentative, or genres. The headline or title defines the event (topic), and conclusion gives important information of an argumentation. The category of assumption is reflected by the global meaning (overall meaning) and also global form (the conventional category). For example, Bad Influences of Romance Series in Television Program is the title, which can be concluded that romance series gives bad moral value to the teenager because the story is all about dating, and caring to the boyfriend/girlfriend only. In the example, the conclusion shows 
personal experience through the romance series. Moreover, it supported by the detail information given such as kissing scene, sexy outfit, and late-night hang out.

\section{Schematic Structures in Context Models}

Interaction in the event is organized by schematic structures for the opening and closing, such as greeting in the news program or speech. It creates a sign to begin and end the communicative event, so people can recognize how to start and close. Moreover, by greeting, the type of the event can be identified whether it is formal or informal. In addition, greeting makes addressing or defining the participant and building the validation of event. As in the news report, headlines are the way to open the reports and it is ended by the summary at last, which can be detected by reading/listening comprehension.

\section{Lexicalization (Style) in Context Models}

Lexical is a cognitive component, which presents the process of mental image in such an opinion. For example, guerrilla and terrorist are able to denote the same object, person, action or event. Context models control social cognition in reflecting people's opinion about event from their knowledge, belief, and attitude. Terrorist is believed to be a part of the bombing or certain event, it is assumed by the knowledge or word terrorist means. On the other hand, event model is controlled by context model by self-definition. It is subjective lexicalization as parent has different way of speaking with their child and adult, which define the feminist or unfeminist representation.

Additionally, when social cognition emphasizes about social or political opinion, self-definition is purposing to deliver social cognition in any possibilities situation (point of view). The repetition of terrorist given by the speaker shows 
that he or she (the speaker) is positioned as a conservative. Lexicalization takes role in controlling ideology of meaning the talk and text (Dijk, 1997).

\section{Syntactic Structures in Context Models}

In underlying event models such semantic information, context manages syntax structures. It is a part of semantic organization which the structures are controlled by pragmatics not event models. For pragmatics, the information is expected by the participants to be recognized even in making the topic. Word order or clause dependency and position decide the important or relevant information, because pragmatics features situation in event models.

\begin{tabular}{|c|c|}
\hline$\frac{\text { Police }}{\mathbf{S}} \underset{\text { vemonstrators }}{ }$ O & $\begin{array}{l}\text {-Focused on police } \\
\text {-The responsibility } \\
\text { and roles agency }\end{array}$ \\
\hline $\begin{array}{l}\text { Demonstrators } \\
\text { police }^{\mathbf{O}}\end{array} \mathbf{v}^{\text {killed }} \mathbf{S}$ by & $\begin{array}{l}\text {-Focused on } \\
\text { demonstrators }\end{array}$ \\
\hline$\frac{\text { Demonstrators }}{\mathbf{S}} \mathbf{v}$ & $\begin{array}{l}\text {-Focused on } \\
\text { demonstrators }\end{array}$ \\
\hline
\end{tabular}

The headline said Police killed demonstrators, has a prominence in police because it killed the object (demonstrators). Here, the headline tries to inform that police has responsibility to this for the role. By the headline, the readers will curious for why the police did it, because syntax gives it position as a subject, which owns an action trough the object. The focus will not be the same as it is changed to passive Demonstrators killed by police. Positioning the subject as an agent after the object can be omitted to Demonstrator killed, which has no information about agent role and responsibility of the police. 
The structure is managed by syntax to show the writer's perspective on event by their self-define in the context. Besides, syntax also formulates the semantic representation of the relevant or important. As the headline example, police is arranged to be the important information, and appeared in semantic representation then. It builds the perception on the event is pro to my group or your group, because syntax has functioned to deliver the goals, intentions, ideologies of the speaker.

\section{Rhetorical Structures in Context Models}

In communicative event, getting the attention might be the focus area. Through stylistic, the relevance can be detected by context coding such as metaphor, alliteration, or irony. However, it is rhetorical devices, which manage, and process the representation. Rhetorical devices contextually control the sense of coding spatial, temporal, or social position of speech participant. For instance, use specific social categories such as basis of age, gender, class, social relation or kinship. The devices are famous as genre to serve the relationship in culture; it elaborates metaphor, alliteration, and irony.

\section{Expression Structures in Context Models}

The structures of expression are managed by level of intonation, stress, standard language, sociolectal or dialectal pronunciation, gesture, face-work, and so on. For example, to present politeness, the speaker might be speaking formally in the speech, taking softly volume, positioning body gesture. On the opposite, the expression of insulting tone, loudness, threatening body position, concomitant face-work and gestures are giving to show racist, sexiest power abuse, and lack of respect.

Furthermore, in the printed news, expression structures can be made up from lay out, print size, pictures and photographs. In the phenomena of minority 
crime, mainly black youth, the journalist tends to highlighted semantic topicalization and schematic position by setting the size of headlines, placing the articles on the page, and supporting photographs, which related to negative implications.

Related to racist, the speaker also rejects for being that way. It is known as disclaimer, one of semantic structures on contextual and cognitive implication. Firstly, the speaker shows specific negative models of the event in the context, and it is followed by general negatives attitudes. Hence, serving disclaimer as positive self-presentation overcomes recipients' contrast evaluation. The social and political situation can be shaped in social image, prestige, the symbolic of speaker's capital, and author/institution. Presenting disclaimer in persuasive discourse established to reduce negative perception. Therefore, it is a big chance for the speaker's argument will be accepted. Moreover, by newspaper and television, social and political influences are wider. For the journalist, highlighting the disclaimer will be contributed in replicating disclaimer of newspaper or news report.

\section{Interpretation Strategies (Nolan, 2005)}

Nolan constructs strategies for bearing the difficulties of interpreting spontaneously. As in the speech (spoken), the speaker's utterances might be too complex, too fast, or ambiguous. Seven strategies construct to catch the speaker's idea. Those are complex syntax which can be done by simplifying the complex sentence (transcribed utterance) to the simple one (SVO), piece by piece (separating one sentence into parts), making long passage into a sentence strategy can be used for having the main idea or sub topic in the speech. Fourth, ambivalent conjunction strategy allows the interpreters to omit them for ambiguity reason. Besides, enumeration strategy makes the shopping list gets easier, because 
it has signal repeated in the beginning. De-verbalization strategy gives imagery to create mental models of the event. Last, compression strategy has acronym and abbreviation to minimalize the words. Parenthetical also belongs to compression, which concludes the idea in the sub topic.

\section{Method}

The approach used in this research is qualitative method, which the data are analyzed by giving explanation. Therefore, qualitative is needed to valid the result by clarifying problems, data, and theories. Describing words or pictures is the focus of qualitative method (Litosseliti, 2010).

Kompas TV narrator and John Kerry are the subjects of this study, which focuses on shifting interpretation. Because of Kompas TV is the only one news report in Indonesia, which performed John Kerry's speech about Syria conflict; it is chosen to be the data. Thus, John Kerry's speech about Syria conflict is also collected as source language.

Through the data obtained process, documentary video technique is suitable for collecting Kompas TV narrator and John Kerry utterances. It transcribed to sentences in order to make the reader easier to understand the analysis. The researcher is the only instrument for all the data composed by the researcher.

Technique data procedure contains of four steps; download the video from Kompas TV and the United States Department channel on YouTube, watch the video, transcribe Kompas TV narrator and John Kerry utterances, and give back translation. The theory of Dijk (1997) supports the analysis of shifting interpretation in meaning structures and organization.

\section{RESULT AND DISCUSSION}


Shifting interpretation in Kompas TV news report can be analyzed by using Dijk's theory of cognitive context models. It has structures and meaning to reveal shifting interpretation in the context (news). Additionally, shift the meaning structure or organization inserted through interpretation strategies process.

\section{Inserting Shifting Interpretation in Semantic Macrostructures on Surface Structures}

The data below show that narrator of Kompas TV shifted meaning by reporting the purpose of ceasefire planed by the United States and Russia is eliminating ISIS's terror and Nusra guerrilla (memberantas teror ISIS dan gerilyawan alnusrah).

\begin{tabular}{|c|c|c|}
\hline $\begin{array}{l}\text { Sourc } \\
\mathrm{e}\end{array}$ & $\begin{array}{l}\text {....And after that } \\
\text { sustained period of } \\
\text { violence, we have } \\
\text { agreed that we will } \\
\text { then work together } \\
\text { - providing both } \\
\text { access and reduced } \\
\text { violence have been } \\
\text { provided for the } \\
\text { period of time - we } \\
\text { would then work } \\
\text { together to develop } \\
\text { military strikes } \\
\text { against Nusrah. }\end{array}$ & $\begin{array}{l}\text { Macro: } \\
\text { Military strikes } \\
\text { to defend from } \\
\text { Nusra violence } \\
\text { Micro: } \\
\text { 1) Work } \\
\text { together } \\
\text { 2) Reduced } \\
\text { violence }\end{array}$ \\
\hline $\begin{array}{l}\text { Targe } \\
\text { t }\end{array}$ & $\begin{array}{l}\text { Selain melakukan } \\
\text { gencatan senjata, } \\
\text { AS dan Rusia juga }\end{array}$ & $\begin{array}{l}\text { Macro: } \\
\text { Violent plan for } \\
\text { Syria }\end{array}$ \\
\hline
\end{tabular}




\begin{tabular}{|c|c|c|}
\hline & $\begin{array}{l}\text { sepakat } \\
\text { membangun pusat } \\
\text { kerjasama militer } \\
\text { untuk } \\
\text { memberantas } \\
\text { terror ISIS dan } \\
\text { gerilyawan al } \\
\text { nursah. }\end{array}$ & $\begin{array}{l}\text { Micro: } \\
\text { 1) Gencatan } \\
\text { senjata } \\
\text { 2) Membangun } \\
\text { pusat } \\
\text { kerjasama } \\
\text { militer } \\
\text { 3) Memberanta } \\
\text { s }\end{array}$ \\
\hline $\begin{array}{l}\text { Back } \\
\text { Trans }\end{array}$ & $\begin{array}{l}\text {....Dan setelah per } \\
\text { berkelanjutan itu, } \\
\text { kami akan beke } \\
\text { menyediakan kedu } \\
\text { mengurangi kekejan } \\
\text { disediakan selama } \\
\text { kami akan bekerj } \\
\text { membangun sero } \\
\text { melawan Nusrah. }\end{array}$ & $\begin{array}{l}\text { iode kekejaman } \\
\text { ami sepakat jika } \\
\text { rja sama - } \\
\text { a akses dan } \\
\text { nan yang telah } \\
\text { ni - selanjutnya } \\
\text { a sama untuk } \\
\text { ngan militer }\end{array}$ \\
\hline
\end{tabular}

The table above maps the semantic macrostructures as surface structure in the context. There are two sides, of course from John Kerry as SL, and Kompas TV for TL. First, the main idea of John Kerry's talk on the data above states that military strikes to defend from Nusra violence. It is supported by John Kerry's repetition of work together and violence, which strengths the point that developing military strikes is one of the plan to negotiate peace in Syria. In this case, semantic macrostructures define the topic of one part of the talk (not the whole speech). Based on Dijk (1997), overall meaning is organized by semantic information. On the table above, work together (the United States and Russia) expresses as the 
plan of overwhelming violence. Second, reduced violence delivers idea that Syria deserves to defend from the violence by Nusra. Local coherence is also provided to present the discourse topic. The events are clear, the United States and Russia plan to work together in three points, develop military strikes is one of them, and those efforts propose to reduce violence by Nusra.

On the other hand, editorial might be given to relate between society response and powerful party. As Kompas TV news program reported that the United States and Russia are not only planning for ceasefire, but also develop partnership in military. Semantic macrostructures take violence plan for Syria as its overall meaning. It sums the detail information of ceasefire, which is one of the plans. The mental image of ceasefire is something that has bomb attacks or guns shot, it is not good witness. It comes from the audiences' knowledge that build in Syria circumstance which surrounded by war issues. Moreover, developing the central military together (the United States and Russia) proposes to succeed the ceasefire. Those two ideas are mentioning to define that the United States and Russia want to eliminate ISIS's terror and Nusra guerrilla. None of the report utterances told about the violence that has been done by ISIS and Nusra. The audiences might give perspective that the plan is not for negotiating peace, but even violent plan for Syria by ceasefire and military development. This news report was affected by social response in building the context. For Indonesia is the big Moslem population, hence Syria conflict could take powerful or political party.

According to semantic macrostructure on the surface structure of the contexts, there is the difference of informing event model. John Kerry event model was military strikes, because the audiences expected to have no knowledge about the plan of the United States and Russia towards Syria conflict. In opposite, the reporter of Kompas TV introduced the elimination of ISIS terror and al-Nusra 
guerrilla as event model of the news. The audiences predicted to be interested in watching the news.

Furthermore, the meaning of memberantas (eliminate) was inappropriate with John Kerry's speech. Based on the sentence structure, against is an adverb which gives detail about military strikes. It means that, the military strikes were arranged to opposite Nusra. On the other hand, the narrator of Kompas TV shifted meaning of against (adverb) to eliminate (memberantas) which is verb. According to Cambridge dictionary, against means in opposition to something. Cambridge dictionary also stated that against is used to protect someone or something from attack or criticism. It compared to memberantas (eliminate), based on Kamus Besar Bahasa Indonesia, the meaning is membasmi; memusnahkan (eliminate). Shifting meaning of against (melawan) to memberantas (eliminate), managed by context model to show the speaker's perspective. John Kerry delivered military strikes as the plan to defend Syria, but Kompas TV narrator reported military strikes are violence plan to eliminate ISIS terror and guerrilla Nusra.

\begin{tabular}{|c|c|c|c|c|c|c|c|c|c|}
\hline We & would & then & work & Together & to & Develop & $\begin{array}{c}\text { military } \\
\text { strikes }\end{array}$ & against & Nusra \\
\hline $\mathrm{S}$ & modal & conj. & $\mathrm{V}$ & adv. & & $\mathrm{V}$ & $\mathrm{N}$ & adv. & $\begin{array}{c}\text { of } \\
\text { place }\end{array}$ \\
\hline
\end{tabular}

\section{Shifting the Interpretation of Lexicalization (Style) in Context Models}

The data proved that Kompas TV narrator shifted meaning of interpreting selfdefinition of Nusra and ISIL in the step planned by the United States and Russia.

\begin{tabular}{|l|l|l|l|}
\hline Source & Halting all of the regime's military air & - Define Nusra and \\
& activities in key areas, key areas that are & ISIL as an \\
& defined - not all flights, because there are still & opposition \\
& Nusrah and ISIL, but that will be managed in a & - Feminist way \\
& different way also. & \\
\hline
\end{tabular}

234 | http://journal.unesa.ac.id/index.php/paramasastra 


\begin{tabular}{|l|l|l|}
\hline Target & $\begin{array}{l}\text { Gencatan ini tak berlaku bagi upaya } \\
\text { pemusnahan kelompok ISIS dan afiliasinya di } \\
\text { Suriah. }\end{array}$ & $\begin{array}{l}\text { - Define ISIS and its } \\
\text { affiliation as a a } \\
\text { group }\end{array}$ \\
\hline $\begin{array}{l}\text { Back } \\
\text { Trans. }\end{array}$ & $\begin{array}{l}\text { Menghentikan semua kegiatan udara militer rezim di area utama, } \\
\text { masih ada Nusrah dan ISIL, tapi itu akan diatur dengan cara yang } \\
\text { berbeda pula. }\end{array}$ \\
\hline
\end{tabular}

First, lexical determines the style of naming ISIS and ISIL, which is affected by the culture. In Indonesia, the group called ISIS for their belief it is only a part of Syria region. In contrast, the United States named the organization as ISIL because they assumed that it is Levant region which is bigger than Syria. Second, John Kerry considered that Syria has to be protected from ISIL and Nusra, therefore not all of the flights were halted. Those two organizations are defined as the opposition as their violence of the bombing in Syria. Besides, the subjective lexicalization that is controlled by context model reflects in the way of defining the opposition. John Kerry did not mention terrorist in this part, because he just started the first step of the plan. By the second and third step of the plan, he defined them as terrorists. The different treat exists because in the beginning he tried to describe the violence first. It shows that context models control the speaker to manage event model with implicitly saying that ISIL and Nusra are the opposition.

On the Kompas TV side, the reported speech was only halting all of the regime's military air activities in key areas. Through complex syntax strategy, the narrator omitted not all flights. It interpreted that the ceasefire was not planned for ISIS and its affiliate. They are not defined as the opposition, because the halted military air activities were the Assad's regime. Moreover, ISIS was 
assumed as an organization by Kompas TV narrator, since they are not the cause of the violence in key areas. By using lexical in addressing kelompok, the narrator defined ISIS as a group of Moslem in Syria region. The other thing was pemusnahan which came from mental image of the Assad air attacks. It has air attacks as an event model, that proceeded by mental image in something hurt by using violence. Yet based on the data above, none of them is recognized as pemusnahan (eliminate), because the steps were all for making both opposition and regime to strict in the peace agreement of Syria.

The context model in John Kerry's speech built nicely, for he said not all flight, because there are still Nusra and ISIL. It is preferable instead of saying to anticipate Nusra and ISIL attacks, several military air activities are needed. Lexically, self-define of terrorist term was implicit and politely said. He believes that Nusra and ISIL are the part of bombing (in the event), then he created mental image of the lexical in his exception of the flight. In this point shifting interpretation was given by changing the way to address ISIS/ISIL and define them in the event model. The news reported of Kompas TV might get question from the audiences, such as what is the purpose of ceasefire? Is that for eliminating ISIS and Nusra (its affiliate) or keeping Syria in peace? By social response, context model in the coming news can be related in order to satisfy the audiences' perception.

\section{Inserting Shifting Interpretation of Syntactic Structures in Context Models}

Shifting interpretation made by the narrator of Kompas TV in reporting the adherence planned by the United States and Russia. The data is typed below

\begin{tabular}{|c|c|c|}
\hline Source & $\begin{array}{l}\text {....we would need seven days of adherence to the } \\
\text { cessation of hostilities in order to convince the } \\
\text { people of Syria and the opposition.... } \\
\text {.... This will be effective at sundown on September }\end{array}$ & $\begin{array}{l}\text { - Focused on seven } \\
\text { days of adherence } \\
\text { - It is an agent role } \\
\text { and responsible }\end{array}$ \\
\hline
\end{tabular}

236 | http://journal.unesa.ac.id/index.php/paramasastra 


\begin{tabular}{|l|l|l|}
\hline Target & $12^{\text {th }}$. & \\
\hline & $\begin{array}{l}\text { Pertemuan itu menghasilkan kesepakatan besar, } \\
\text { yakni gencatan senjata akan dilakukan di suriah } \\
\text { per tanggal } 12 \text { September 2016; belum ada } \\
\text { keterangan lebih lanjut terkait jangka waktu } \\
\text { gencatan senjata. }\end{array}$ & September 2016 \\
\hline Brack & $\begin{array}{l}\text {...kami akan memerlukan tujuh hari kepatuhan untuk penghentian } \\
\text { permusuhan untuk meyakinkan rakyat Suriah dan oposisi.... } \\
\text {....Ini akan efektif saat matahari terbenam pada 12 September. }\end{array}$ \\
\hline
\end{tabular}

The syntactic structures of John Kerry's statement are focused on the seven days of adherence to the cessation of hostilities rather than the following phrase. Even though it is not the subject, but it is positioned as the information in the sentence in prepositional phrase (PP). It contains two noun phrase (NP), which are all the messages of the sentence. First, seven days of adherence told that there will be an action to bring the rules back. It is the opposition who breaks the rules in the agreement about peace in Syria. Therefore, the United States and Russia need seven days to adhere the opposition. Second, the cessation of hostilities specified that seven days of adherence is to stop the war. It means the ceasefire will take seven days and it starts from September $12^{\text {th }}$. In addition, this sentence also presented the agent role of the United States and Russia in negotiating peace in Syria. Because of the agreement did not work, they took the responsibility to adhere the opposition. The adherence planned by ceasefire and developing military strikes. It mentioned in the first and second step of John Kerry's speech.

In contrast, the narrator of Kompas TV shifted seven days of adherence by reporting belum ada keterangan lebih lanjut terkait jangka waktu 
gencatan senjata (there is no further information about how long ceasefire takes time). The reporter emphasized on the start of the ceasefire on September $12^{\text {th }}$. It became semantic representation that introduced to the audiences. In this case, the reporter showed his/her opinion through adherence period. Kompas TV was about in contra about the event (ceasefire). Thus, the important information was only the start-date of ceasefire, because Kompas TV assumed if the adherence will not only take seven days.

According to the context model, syntax gives signal on the relevant information as the table below. This clause determined that the event model is ending the fight in seven days. On John Kerry's speech, prepositional phrase was used to build the perception of stopping the hate. The opposition has to be in line with the agreement of peace in Syria. Hence, for this purpose the subject (we; refers to the United States and Russia) has role in taking responsibility of the step.

\begin{tabular}{|c|c|c|c|c|l|}
\hline We & would & need & seven days of adherence & to & the cessation of hostilities \\
\hline S & modal & V & \multicolumn{3}{|c|}{ Prepositional Phrase } \\
\hline
\end{tabular}

\section{Shifting the Interpretation of Expression Structures in Context Models}

The data below proved that John Kerry's point of encouraging Assad and opposition was shifted by Kompas TV narrator.

\begin{tabular}{|l|l|l|}
\hline Source & $\begin{array}{l}\text { Obviously, the Russians have an ability to } \\
\text { be able to encourage Assad, and we have } \\
\text { an ability together with other countries to } \\
\text { encourage the opposition. }\end{array}$ & $\begin{array}{l}\text { - Racism marked by } \\
\text { obviously } \\
\text { - Positive as persuasive } \\
\text { discourse }\end{array}$ \\
\hline Target & $\begin{array}{l}\text { Hingga kini, Rusia masih ingin } \\
\text { mempertahankan Bashar Al-Assad sebagai } \\
\text { Presiden Suriah, sementara Amerika } \\
\text { Serikat menginginkan Assad lengser dari } \\
\text { jabatannya. }\end{array}$ & $\begin{array}{l}\text { - Racism marked by the } \\
\text { contrary of Russia and } \\
\text { the United States } \\
\text { Assad Bashar al- }\end{array}$ \\
\hline
\end{tabular}

238 | http://journal.unesa.ac.id/index.php/paramasastra 


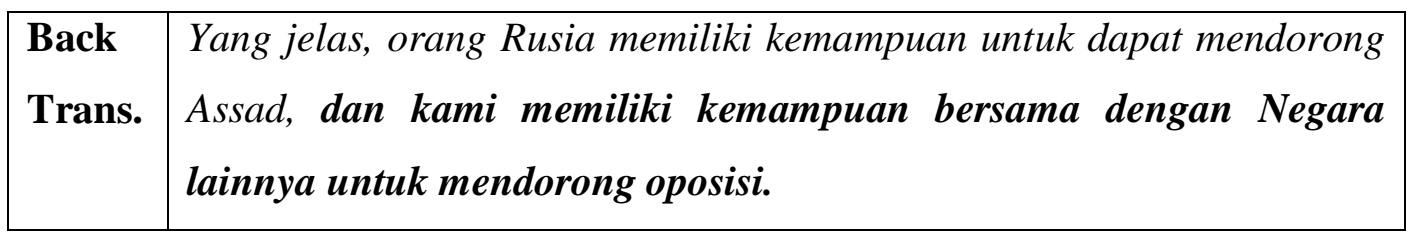

First of all, obviously starts the racist of Russia was in Assad's side. To John Kerry, Russians have an ability to encourage Assad and it is obviously. In this case, the United States was not mentioned to encourage Assad. However, we (refers to the United States and Russia) stated to encourage the opposition, after that. It seems that encouraging Assad and opposition was the part of the plan. Both the United States and Russia work together for making peace in Syria, with dividing role into Russia covers Assad, the United States, Russia, and other countries cover the opposition. According to expression structures, John Kerry's intonation in delivering this point was smooth, means that he politely said Russians are able to cover Assad without the United States. Thus, he rejected the possible negative response by adding that the United States will be involved in encourage the opposition. It sounds as I am not racist because I am not encouraging Assad.

Conversely, the narrator of Kompas TV stated that Rusia masih ingin mempertahankan Bashar Al-Assad sebagai Presiden Suriah (Russia still wants Assad to be the President of Syria). It supported by the photograph of Barrack Obama (the President of US) and Vladimir Putin (the President of Russia) and Bashar al-Assad (the President of Syria) in the news report. The stress of intonation was little bit higher which signed the expression of relevant information. In addition, the reporter was also racist by delivering sementara Amerika Serikat menginginkan Assad lengser dari jabatannya (on the other hand, the United States wants Assad discharged from his position). Based on the context model, social and political were comprised to show personal opinions 
towards event. The context controlled the event of the United States disagreed with Assad as a president, which was expressed by Kompas TV.

The shifting interpretation inserted by different way of showing respect. John Kerry believes that Russia has ability to encourage Assad because it handles big involvement in Middle-East (Rahman, 2017). Likewise, he denied of being racist by declaring that the United States involved in encourage the opposition. In contrast, due to not encourage Assad, but the opposition, Kompas TV narrator interpreted it as the United States wants Assad off from his position as a Syria President. It was expressed by changing personal's opinion through social and political in the event model (encourage Assad and opposition).

\section{CONCLUSION}

Four shifts are found in Kompas TV news interpretation. Each shift has different way to be inserted, depends on the structure. By changing the surface structures, Kompas TV shows different perception of military strikes. It has semantic macro and micro structures that define the important information based on the overall meaning and its details. Moreover, shifting given by changing lexicalization of delivering information about ISIS/ISIL. It works on selfdefinition of something affected by environmental perception. While John Kerry means ISIL as the opposition, Kompas TV reported that it is only an organization. The third shifting involves syntactic structures on positioning information as the relevant. John Kerry's context models control prepositional phrase as the important information, but it was omitted by Kompas TV. The last shift revealed by expression structures in context models. In this case, disclaimer exists to reject the racist expression of encouraging Assad as the president of Syria.

There are four strategies found in this research, those are complex syntax, making long passage into a sentence, de-verbalization, and compression. All of the strategies help to shorten the utterances. According to Nolan (2005), 
interpretation needs the understanding of meaning rather than translating all the words. Complex syntax deals with the structure and meaning to shorten the complex sentence. Shifting is given by Kompas TV narrator to build perception of the audiences. Interpretation strategies can be used for examining narrator of Kompas TV in transforming John Kerry's speech in Indonesian. The meaning changed impacts to the context model which presents the event. Cognitive context models and discourse structures are related to reveale that shifting in interpretation is required for controlling people think about the world.

\section{SUGGESTION}

This research was emphasized on examining interpretation strategies; there are two suggestions for the research in the future. It is interesting to understand how people transform one language to another. Therefore, analysing the interpretation deeper to the general adverbial is suggested.

Second, connecting interpretation to cognitive context models might motivate the future researcher to analyse the context of interpretation which shows someone's power. Having rhetorical structures in translating context of the novel is also exiting. It is how semantic and discourse are building power in society perspective.

\section{REFERENCES}

Dijk, Teun A. van. (1997). Cognitive Context Models and Discourse. Amsterdam: Benjamins.

Litosseliti, Lia. (2010). Research Methods in Linguistics. London: Continuum.

Nolan, James. (2005). Interpretation Techniques and Exercises. Great Britain: Cromwell Press Ltd. 
Okoniewska, Alicja M. (2016). Interpreting for the European Parliament. Precision or illusion.

Putra, Kresna Pramuaji Isantara. (2015). Translation Shifts of Prepositional Phrases from English to Indonesian Novel The Da Vinci Code. 